\title{
Examination of Acceleration and Speed Performances According to Different Foot Sole Sizes in Sedentary Women
}

\author{
Cengiz Taşkin (Corresponding author) \\ Department of Physical Education and Sport, School of Physical Education and Sport \\ Kilis 7 Aralık University, Mehmet Sanlı Mah. Doğan Güreş Paşa Bul. No:134 Kilis, Turkey \\ Tel: 90-348-814-2666Ｅ-mail: taskin.c@hotmail.com
}

\begin{abstract}
Ali Kemal Taşkin
Department of Physical Education and Sport, School of Physical Education and Sport Kilis 7 Aralık University, Mehmet Sanlı Mah. Doğan Güreş Paşa Bul. No:134 Kilis, Turkey

Tel: 90-348-814-2666 E-mail: kemaltaskin@kilis.edu.tr
\end{abstract}

Received: October 13, 2021 Accepted: November 25, 2021

Published: December 1, 2021

doi:10.5296/jei.v7i2.19095 URL: https://doi.org/10.5296/jei.v7i2.19095

\begin{abstract}
In this study, it was aimed to examine the acceleration and speed performances of sedentary women according to their different foot sole length. 60 women that recide in Gaziantep and live sedentary life has participated voluntarily. The subjects were divided into 4 groups in terms of foot sole length and metatarsus width. The average age of the subjects that are participated in the study is determined as $15.8 \pm 0.76$ for the 1st group, $16.1 \pm 1.13$ for the 2 nd group, $15.9 \pm 1.12$ for the 3rd group and $15.7 \pm 1.33$ for the 4 th group. Foot sole, metatarsus measurements, acceleration and speed performance values of the subjects were taken in accordance with the measurement technique. All data that is obtained in the study were compared with each other and analyzed in terms of groups while using the SPSS 20.0 software package. When we evaluate the results of the analysis; it can be seen that there are significant differences that is detected between the 1st, 3rd and 4th groups in terms of acceleration performance in terms of foot sole length and metatarsus width; however, no significant difference was found between the 2nd group and the other groups. Although small
\end{abstract}


differences were detected between the groups when it comes to sprint performance, these differences were not statistically significant. As a result, it was observed that there were differences between the groups in terms of acceleration performance, but there was no significant difference in terms of speed performance.

Keywords: Acceleration, Foot sole, Handball

\section{Introduction}

Although there are many studies on athletes, it is aimed to maximize the development by adding new information and findings to the information that is currently available in order to do more and continue the progress and maintain the importance of the need for new research.

Acceleration is the rate of change in speed that allows the athlete to reach the maximum speed in the least amount of time (Gambetta, 1996). Maximum speed is the maximum velocity that the athlete can run. For the success of the athletes, it is possible to actively reach the maximum running speed and accelerate. During to reach maximum speed, conditioning and strength program's level are important and they improve the two basic elements of velocity. To reach the maximum speed, conditioning and strength programs are on important level and they improve the two basic elements of speed. These are acceleration and velocity. Acceleration is defined as the rate of variation in speed as we mentioned before and it is often measured using the performance of running sprints over distances that are not too long such as 5 or 10 meters. Speed refers to the rate of movement within a predetermined range (Murphy et al., 2003). It is performed by increasing the physical, metabolic and neurological elements that is associated with sprinting in order to bring acceleration and speed to a good level (Facciono, 1993). The ability to reach maximum running speed in a short time is an important key to success in sports branches like football, athletics, rugby and American football (Bangsbo et al., 1991).

Physical fitness values, which include the physical physiological characteristics of athletes, are important in determining talent selection. The main reasons for the success of the countries that participate and are successful in international sports competitions are their infrastructure, facilities, trainers and technologies. Also, it can be shown as a very systematic work in selecting and directing children to sports branches where they can be talented at the most appropriate time. Our feet both enable us to contact the earth and carry all the weight of our body. Therefore, they are a very important organ of our ability to move. Normal anatomical structure of our feet are important that they provide our social and physiological needs. Since the feet are our organs within the contact of the earth, they are vitally important for optimum performance in many sports branches. For this reason, researches on foot structure can present up-to-date and practical data concerning a large audience. In this study, we compared and interpreted acceleration and speed performances with different foot sole measurements.

It is thought that this study will provide convenience to the trainers in the selection of sportsmen specific to the branch and in performance-oriented sports training. 


\section{Method}

\subsection{Participants}

Sixty women that recide in Gaziantep and live sedentary life participated voluntarily in the study. Twenty-four hours before the beginning of study, the subjects were informed about the research and asked to get prepared with the clothes as required for the study. The age, height, weight and body mass index values of the subjects that participated in the study has been chosen carefully close to each other's values. In addition, the subjects selected for our study were selected from healthy individuals who did not have anatomical disorders by determining the lower and upper limits of the foot sole and metatarsus sizes. The tests that is used were carried out by using the necessary tools and equipment in the indoor sports hall and by resting the participants throughout the study.

\subsection{Data Collection Tools}

Height: The height of the test subjects was measured by standing still on a flat surface without shoes, holding their breath, with heels and two big toes together, and using a stadiometer (SECA, Germany) with a precision of $0.01 \mathrm{~m}$ and a measurement suitable for the desired measurement technique.

Body Weight: To get the full results from weight measurements, they were taken at 09:00 in the morning, assuming that the individuals participating in the study do not usually fill their satiety levels. When weight measurements were made, it was paid attention that the subjects were without shoes and wearing sports clothes (tracksuits and t-shirts), and the results were measured with the desired measurement technique which is an electronic scale (SECA, Germany) with a precision of $0.1 \mathrm{~kg}$.

Body Mass Index Calculation (BMI): The body mass index of the subjects was calculated by dividing the body weight in kilograms by the square of the height in meters with the formula accepted by the World Health Organization.

$$
\text { Body Mass Index }(\text { BMI })=\text { Body Weight }(\mathrm{kg}) / \text { Height Squared }\left(\mathrm{m}^{2}\right)
$$

Foot Sole Length Measurement: Subjects' foot length was placed on a clean piece of paper. The circumference of the foot was drawn with a pencil, holding it perpendicular to the paper (at a 90 degree angle). The distance between the backmost point of the heel and the tip of the toe was measured with a shoe measure tape, and the length was measured with a stadiometer (SECA, Germany) that has a degree of precision of $0.01 \mathrm{~m}$ in accordance to the desired measurement technique (M.E.B. Megep, 2013).

Metatarsus Width Measurement: The forefoot width of the subjects was measured which is the distance between the extreme points of the junction of the first (thumb) toe and the metatarsal of the fifth (little finger) to the metatarsus with a stadiometer (SECA, Germany) that has an accuracy of $0.01 \mathrm{~m}$. 


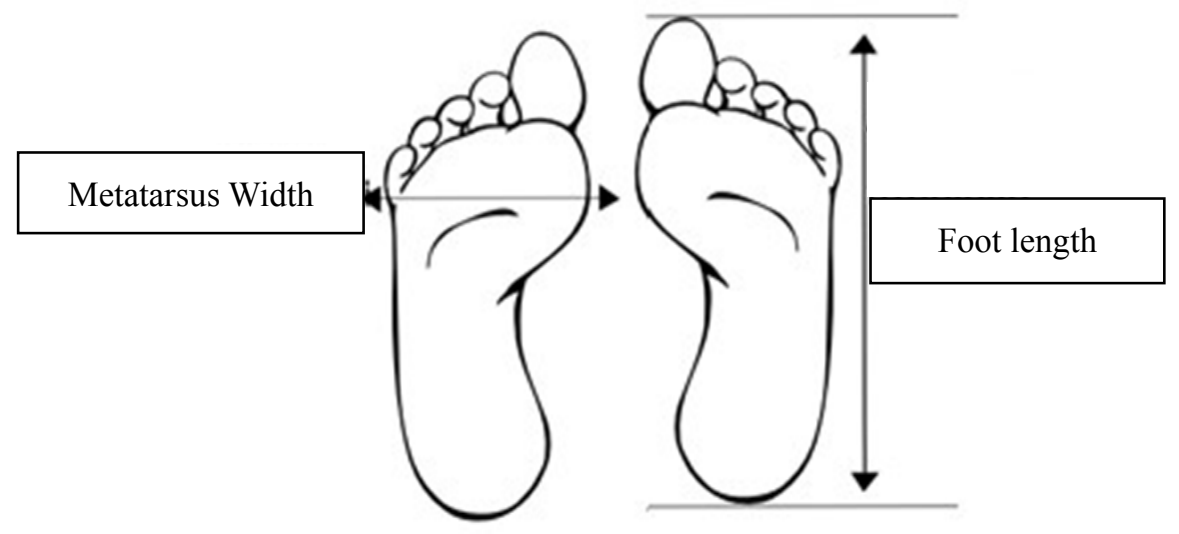

Acceleration Test: The track continues in the same direction with a length of 15 meters. It is divided into three sections which are 5,10 and 15 meters. Two slalom and one photocell are installed for each five meters. It consists of 6 slalom and three photocells in total. The person who will enter the track is brought to the starting point by calling his name, and it is ensured that he takes a running position with one of his feet bent at the knee and the other one straight at the back. He is not allowed to take a step back. After waiting in this position for a maximum of 3 seconds, he starts running at maximum speed with the ready and exit commands. Measurement results are written in seconds and each athlete is given 3 attempts. All subjects are not allowed to proceed to the second attempt until the first attempt is over. The best graded trials of the sedantary who completed all three trials at 5,10 and 15 meters were recorded.

30 m Speed Run: Measurements were made on a standard $45 \mathrm{~m}$ indoor running track. Its length and ground characteristics were the same for all subjects. The start and finish lines are set in a ground with a straight line. At the starting and $30 \mathrm{~m}$. ending line, photocell is placed. In addition, the starting and ending points are determined with signs (funnel, etc.). The subjects were given three trials and a five-minute rest between each trial and the best time of the three trials was evaluated.

\subsection{Statistical Analysis}

All data obtained in the study were analyzed in the SPSS 20.0 software package program. Whether the data has showed normal distribution or not was determined by using the Kolmogorov-Smirnov test. Since it showed normal distribution, one-way analysis of variance, One-Way Anova test, was used to determine whether the acceleration and speed values of the handball players differ according to their positions. As a result of the comparisons, Tukey HSD method which is one of the Post Hoc multiple comparison tests was used to determine between in which groups the difference has occurred. In this study, the significance level was taken as 0.05 . 


\section{Results}

Table 1. Descriptive statistics values of the subjects

\begin{tabular}{|c|c|c|c|c|}
\hline Variables & $\begin{array}{l}\text { Foot Sole Length: } \\
19.0 \text { and } 20.0 \mathrm{~cm} \text {; } \\
\text { Metatarsus Width: } \\
8.0 \text { and } 8.5 \mathrm{~cm}\end{array}$ & $\begin{array}{l}\text { Foot Sole Length: } \\
20.1 \text { and } 21.0 \mathrm{~cm} \text {; } \\
\text { Metatarsus Width: } \\
8.6 \text { and } 9.0 \mathrm{~cm}\end{array}$ & $\begin{array}{l}\text { Foot Sole Length: } \\
21.1 \text { and } 22.0 \mathrm{~cm} \text {; } \\
\text { Metatarsus Width: } \\
9.1 \text { and } 9.5 \mathrm{~cm}\end{array}$ & $\begin{array}{l}\text { Foot Sole Length: } \\
22.1 \text { and } 23.0 \mathrm{~cm} \text {; } \\
\text { Metatarsus Width: } \\
9.6 \text { and } 10.0 \mathrm{~cm}\end{array}$ \\
\hline $\mathbf{N}$ & 15 & 15 & 15 & 15 \\
\hline Percentage (\%) & 25 & 25 & 25 & 25 \\
\hline
\end{tabular}

When Table 1 is examined, it is observed that the number and percentage values of the groups participating in the research are discussed.

Table 2. Classification of the subjects according to foot sizes

\begin{tabular}{|c|c|c|c|c|}
\hline Variables & $\begin{array}{l}\text { Foot Sole Length: } \\
19.0 \text { and } 20.0 \mathrm{~cm} \text {; } \\
\text { Metatarsus Width: } \\
8.0 \text { and } 8.5 \mathrm{~cm}\end{array}$ & $\begin{array}{l}\text { Foot Sole Length: } \\
20.1 \text { and } 21.0 \mathrm{~cm} \text {; } \\
\text { Metatarsus Width: } \\
8.6 \text { and } 9.0 \mathrm{~cm}\end{array}$ & $\begin{array}{l}\text { Foot Sole Length: } \\
21.1 \text { and } 22.0 \mathrm{~cm} \text {; } \\
\text { Metatarsus Width: } \\
9.1 \text { and } 9.5 \mathrm{~cm}\end{array}$ & $\begin{array}{l}\text { Foot Sole Length: } \\
22.1 \text { and } 23.0 \mathrm{~cm} \text {; } \\
\text { Metatarsus Width } \\
9.6 \text { and } 10.0 \mathrm{~cm}\end{array}$ \\
\hline Group Number & Group 1 & Group 2 & Group 3 & Group 4 \\
\hline N (number) & 15 & 15 & 15 & 15 \\
\hline
\end{tabular}

When Table 2 is examined, it is observed that the classification table of the subjects that participated in the research is handled according to the sole and metatarsus measurements. 
Table 3. Descriptive statistical values of the foot sole length and metatarsus width of the subjects that participated in the study

\begin{tabular}{|c|c|c|c|c|}
\hline \multirow[b]{2}{*}{ Variables } & \multicolumn{4}{|c|}{$\begin{array}{l}\text { Foot Sole Lenght } \\
\text { Metatarsus Width }\end{array}$} \\
\hline & $\begin{array}{l}19.0 \text { and } 20.0 \mathrm{~cm} \\
8.0 \text { and } 8.5 \mathrm{~cm}\end{array}$ & $\begin{array}{l}20.1 \text { and } 21.0 \mathrm{~cm} \\
8.6 \text { and } 9.0 \mathrm{~cm}\end{array}$ & $\begin{array}{l}21.1 \text { and } 22.0 \mathrm{~cm} \\
9.1 \text { and } 9.5 \mathrm{~cm}\end{array}$ & $\begin{array}{l}22.1 \text { and } 23.0 \mathrm{~cm} \\
9.6 \text { and } 10.0 \mathrm{~cm}\end{array}$ \\
\hline Age (Year) & $15.8 \pm 0.76$ & $16.10 \pm 1.13$ & $15.9 \pm 1.12$ & $15.7 \pm 1.33$ \\
\hline Height (cm) & $160.4 \pm 2.65$ & $160.1 \pm 2.01$ & $159.8 \pm 1.56$ & $159.3 \pm 1.73$ \\
\hline Weight (kg) & $57.68 \pm 2.89$ & $57.15 \pm 2.11$ & $57.88 \pm 1.99$ & $58.23 \pm 2.76$ \\
\hline BMI $\left(\mathrm{kg} / \mathrm{m}^{2}\right)$ & $22.41 \pm 1.44$ & $22.29 \pm 1.54$ & $22.66 \pm 1.76$ & $22.96 \pm 2.01$ \\
\hline
\end{tabular}

When Table 3 is examined, the statistical data of the age, height, weight and body mass index average values of the subjects according to feet sole length and metatarsus width are given.

Table 4. Comparison of the physical parameters of the subjects according to the foot sole measurements

\begin{tabular}{|c|c|c|c|c|c|c|}
\hline Variables & $\begin{array}{l}\text { Foot Sole Lenght } \\
\text { Metatarsus Width }\end{array}$ & Average & $\begin{array}{l}\text { Standard } \\
\text { Deviation }\end{array}$ & $\mathbf{F}$ & $\mathbf{P}$ & Gap \\
\hline \multirow{4}{*}{ Age (Year) } & $\begin{array}{l}19.0 \mathrm{~cm} \text { and } 20.0 \mathrm{~cm} \\
8.0 \mathrm{~cm} \text { and } 8.5 \mathrm{~cm}\end{array}$ & 15.8 & 0.76 & & & \\
\hline & $\begin{array}{l}20.1 \mathrm{~cm} \text { and } 21.0 \mathrm{~cm} \\
8.6 \mathrm{~cm} \text { and } 9.0 \mathrm{~cm}\end{array}$ & 16.10 & 1.13 & 0.148 & 0.902 & \\
\hline & $\begin{array}{l}21.1 \mathrm{~cm} \text { and } 22.0 \mathrm{~cm} \\
9.1 \mathrm{~cm} \text { and } 9.5 \mathrm{~cm}\end{array}$ & 15.9 & 1.12 & & & \\
\hline & $\begin{array}{l}22.1 \mathrm{~cm} \text { and } 23.0 \mathrm{~cm} \\
9.6 \mathrm{~cm} \text { and } 10.0 \mathrm{~cm}\end{array}$ & 15.7 & 1.33 & & & \\
\hline \multirow{3}{*}{ Height $(\mathrm{cm})$} & $\begin{array}{l}19.0 \mathrm{~cm} \text { and } 20.0 \mathrm{~cm} \\
8.0 \mathrm{~cm} \text { and } 8.5 \mathrm{~cm}\end{array}$ & 160.4 & 2.65 & & & \\
\hline & $\begin{array}{l}20.1 \mathrm{~cm} \text { and } 21.0 \mathrm{~cm} \\
8.6 \mathrm{~cm} \text { and } 9.0 \mathrm{~cm}\end{array}$ & 160.2 & 2.01 & 0.689 & 0.549 & \\
\hline & $\begin{array}{l}21.1 \mathrm{~cm} \text { and } 22.0 \mathrm{~cm} \\
9.1 \mathrm{~cm} \text { and } 9.5 \mathrm{~cm}\end{array}$ & 159.8 & 1.56 & & & \\
\hline
\end{tabular}




\begin{tabular}{|l|l|l|l|l|l|l|}
\hline & $\begin{array}{l}22.1 \mathrm{~cm} \text { and } 23.0 \mathrm{~cm} \\
9.6 \mathrm{~cm} \text { and } 10.0 \mathrm{~cm}\end{array}$ & 159.3 & 1.73 & & & \\
\hline \multirow{5}{*}{ Weight $(\mathrm{kg})$} & $\begin{array}{l}19.0 \mathrm{~cm} \text { and } 20.0 \mathrm{~cm} \\
8.0 \mathrm{~cm} \text { and } 8.5 \mathrm{~cm}\end{array}$ & 57.68 & 2.89 & & & \\
\cline { 2 - 8 } & $\begin{array}{l}20.1 \mathrm{~cm} \text { and } 21.0 \mathrm{~cm} \\
8.6 \mathrm{~cm} \text { and } 9.0 \mathrm{~cm}\end{array}$ & 57.15 & 2.11 & 0.381 & 0.743 & \\
\cline { 2 - 8 } & $\begin{array}{l}21.1 \mathrm{~cm} \text { and } 22.0 \mathrm{~cm} \\
9.1 \mathrm{~cm} \text { and } 9.5 \mathrm{~cm}\end{array}$ & 57.88 & 1.99 & & & \\
\cline { 2 - 8 } & $\begin{array}{l}22.1 \mathrm{~cm} \text { and } 23.0 \mathrm{~cm} \\
9.6 \mathrm{~cm} \text { and } 10.0 \mathrm{~cm}\end{array}$ & 58.23 & 2.76 & & & \\
\hline \multirow{5}{*}{ BMI } & $\begin{array}{l}19.0 \mathrm{~cm} \text { and } 20.0 \mathrm{~cm} \\
8.0 \mathrm{~cm} \text { and } 8.5 \mathrm{~cm}\end{array}$ & 22.42 & 1.44 & & & \\
\cline { 2 - 8 } & $\begin{array}{l}20.1 \mathrm{~cm} \text { and } 21.0 \mathrm{~cm} \\
8.6 \mathrm{~cm} \text { and } 9.0 \mathrm{~cm}\end{array}$ & 22.29 & 1.54 & 0.571 & 0.601 & \\
\cline { 2 - 8 } & $\begin{array}{l}21.1 \mathrm{~cm} \text { and } 22.0 \mathrm{~cm} \\
9.1 \mathrm{~cm} \text { and } 9.5 \mathrm{~cm}\end{array}$ & 22.66 & 1.76 & & & \\
\hline & $\begin{array}{l}22.1 \mathrm{~cm} \text { and } 23.0 \mathrm{~cm} \\
9.6 \mathrm{~cm} \text { and } 10.0 \mathrm{~cm}\end{array}$ & 22.96 & 2.01 & & & \\
\hline
\end{tabular}

Note. ${ }^{*}$ significance at $\mathrm{p}<0.05$ level.

When Table 4 is examined, it was determined that the age, height, weight and body mass index values of all groups classified according to foot sole length and metatarsus width were close to each other and there was no statistically significant difference between them $(\mathrm{p}>$ $0.05)$.

Table 5. Comparison of the foot sole measurements of the subjects with the acceleration and speed degrees

\begin{tabular}{|l|l|l|l|l|l|l|}
\hline Variables & $\begin{array}{l}\text { Foot Sole Lenght } \\
\text { Metatarsus Width }\end{array}$ & Average & $\begin{array}{l}\text { Standard } \\
\text { Deviation }\end{array}$ & F & P & Gap \\
\hline \multirow{5}{*}{5 Meter (sn) } & $\begin{array}{l}19.0 \mathrm{~cm} \text { and } 20.0 \mathrm{~cm} \\
8.0 \mathrm{~cm} \text { and } 8.5 \mathrm{~cm}\end{array}$ & 1.28 & 0.07 & & & \\
\cline { 2 - 8 } & $\begin{array}{l}20.1 \mathrm{~cm} \text { and } 21.0 \mathrm{~cm} \\
8.6 \mathrm{~cm} \text { and } 9.0 \mathrm{~cm}\end{array}$ & 1.24 & 0.05 & 5.673 & $0.000^{*}$ & $1-3$ \\
\cline { 2 - 8 } & $\begin{array}{l}21.1 \mathrm{~cm} \text { and } 22.0 \mathrm{~cm} \\
9.1 \mathrm{~cm} \text { and } 9.5 \mathrm{~cm}\end{array}$ & 1.20 & 0.06 & & & $1-4$ \\
\hline
\end{tabular}




\begin{tabular}{|c|c|c|c|c|c|c|}
\hline & $\begin{array}{l}22.1 \mathrm{~cm} \text { and } 23.0 \mathrm{~cm} \\
9.6 \mathrm{~cm} \text { and } 10.0 \mathrm{~cm}\end{array}$ & 1.21 & 0.07 & & & \\
\hline \multirow{4}{*}{10 Meter (sn) } & $\begin{array}{l}19.0 \mathrm{~cm} \text { and } 20.0 \mathrm{~cm} \\
8.0 \mathrm{~cm} \text { and } 8.5 \mathrm{~cm}\end{array}$ & 2.29 & 0.15 & & & \\
\hline & $\begin{array}{l}20.1 \mathrm{~cm} \text { and } 21.0 \mathrm{~cm} \\
8.6 \mathrm{~cm} \text { and } 9.0 \mathrm{~cm}\end{array}$ & 2.25 & 0.11 & 3.408 & $0.012^{*}$ & $1-3$ \\
\hline & $\begin{array}{l}21.1 \mathrm{~cm} \text { and } 22.0 \mathrm{~cm} \\
9.1 \mathrm{~cm} \text { and } 9.5 \mathrm{~cm}\end{array}$ & 2.22 & 0.12 & & & $1-4$ \\
\hline & $\begin{array}{l}22.1 \mathrm{~cm} \text { and } 23.0 \mathrm{~cm} \\
9.6 \mathrm{~cm} \text { and } 10.0 \mathrm{~cm}\end{array}$ & 2.20 & 0.16 & & & \\
\hline \multirow{4}{*}{15 Meter (sn) } & $\begin{array}{l}19.0 \mathrm{~cm} \text { and } 20.0 \mathrm{~cm} \\
8.0 \mathrm{~cm} \text { and } 8.5 \mathrm{~cm}\end{array}$ & 3.17 & 0.16 & & & \\
\hline & $\begin{array}{l}20.1 \mathrm{~cm} \text { and } 21.0 \mathrm{~cm} \\
8.6 \mathrm{~cm} \text { and } 9.0 \mathrm{~cm}\end{array}$ & 3.13 & 0.14 & 2.381 & $0.017^{*}$ & $1-3$ \\
\hline & $\begin{array}{l}21.1 \mathrm{~cm} \text { and } 22.0 \mathrm{~cm} \\
9.1 \mathrm{~cm} \text { and } 9.5 \mathrm{~cm}\end{array}$ & 3.09 & 0.15 & & & $1-4$ \\
\hline & $\begin{array}{l}22.1 \mathrm{~cm} \text { and } 23.0 \mathrm{~cm} \\
9.6 \mathrm{~cm} \text { and } 10.0 \mathrm{~cm}\end{array}$ & 3.10 & 0.14 & & & \\
\hline \multirow{4}{*}{30 M. Speed (sn) } & $\begin{array}{l}19.0 \mathrm{~cm} \text { and } 20.0 \mathrm{~cm} \\
8.0 \mathrm{~cm} \text { and } 8.5 \mathrm{~cm}\end{array}$ & 5.31 & 0.17 & & & \\
\hline & $\begin{array}{l}20.1 \mathrm{~cm} \text { and } 21.0 \mathrm{~cm} \\
8.6 \mathrm{~cm} \text { and } 9.0 \mathrm{~cm}\end{array}$ & 5.29 & 0.15 & 0.702 & 0.529 & \\
\hline & $\begin{array}{l}21.1 \mathrm{~cm} \text { and } 22.0 \mathrm{~cm} \\
9.1 \mathrm{~cm} \text { and } 9.5 \mathrm{~cm}\end{array}$ & 5.27 & 0.14 & & & \\
\hline & $\begin{array}{l}22.1 \mathrm{~cm} \text { and } 23.0 \mathrm{~cm} \\
9.6 \mathrm{~cm} \text { and } 10.0 \mathrm{~cm}\end{array}$ & 5.35 & 0.15 & & & \\
\hline
\end{tabular}

Note. ${ }^{*}$ significance at $\mathrm{p}<0.05$ level.

When Table 5 is examined, there is a statistically significant difference was found between the 1st and 3rd groups in favor of the 3rd, and between the 1st and 4th groups in favor of the 4th groups within the comparison of the groups classified according to foot sole length and metatarsus width with the acceleration performance values of 5-10-15 meters; $(p<0.05)$. In addition, as a result of the statistical evaluation, although there were differences between the values of 1st and 2nd groups, 2nd and 3rd and 4th groups, and 3rd and 4th groups, there is no statistically significant differences were found in these differences $(p>0.05)$.

\section{Discussion}

In this study, the acceleration and speed performances of women with different foot sole 
length and metatarsus width were examined. In our study, measurements in the literature were used for acceleration and speed measurements. During the study, the subjects that participated in the study were individuals with no statistical differences in terms of age, height, weight and body mass index values. It was thought that our study would reflect negatively on our results, since the sole and instep measurements of individuals in the same age group but with different body mass indexes would also differ. It was thought that our study would reflect negatively on our results, since the sole and metatarsus measurements of individuals in the same age group with different body mass indexes may also differ. As a matter of fact, it was observed that the arch structure of the foot was impaired due to the pressure exerted by the excess weight on the feet in people with a higher body mass index in a study on judokas (Andrzejewska et al., 2010).

At the end of our study, when the acceleration performance values of the groups classified according to the foot sole length and metatarsus width measurements were compared with each other, it is found that there is statistically difference in favor of groups 3 and 4 between groups group 1, group 3 and group 4 in all 5-10 and 15 meters values. In our study, it was determined that the acceleration performance values were positively affected when the foot sole length and metatarsus width increased. When the relationship between foot sole measurements and quickness - agility values were examined in a study, it was determined that foot sole width and length had a positive effect on quickness and agility performance (Taşkın et al., 2020). The balance feature is an important factor in the positive acceleration performances of the subjects in our research because balance skill is the ability to correctly position the center of gravity on the rest support surface during physical activity and rest (Erdoğan et al., 2017). The center of gravity is provided by the relationship between the support surface and the gravity line. The support surface is the area between the ground and the ground contact points of a subject. In balanced stance, the point where the gravity line intersects with the ground falls into the support surface (Koyuncu, 2013). In balanced stance, the point where the gravity line intersects with the ground falls into the support surface (Koyuncu, 2013). This shows that foot sole and metatarsus measurements are an important component of physical fitness in balance ability. In a study that is examining the effect of proprioception training on acceleration, it was determined that increased proprioception sense had a positive effect on acceleration performance (Taşkın \& Biçer, 2015). In another study, it has been determined that there is a positive correlation between wider and longer foot sole measurements and balance performance (Taşkın et al., 2020). When we look at the results of our study, we see that they overlap with the information in the literature. In addition, there is no statistically significant difference was found between the sprint performance values of the subjects and groups 1, 2, 3 and 4 classified in our study according to the size of the sole and the metatarsus.

As a result of our study, the reason why there is no significance was found between the speed performance and the foot sole and comb measurements is the ability to perform the movements as soon as possible and correctly as a result of the harmonious operation of the speed, muscle and nervous system (Taşkıran, 2007). In addition, muscular and cardiovascular endurance, strength, coordination, body structure and composition also depend on physical 
and physiological characteristics (Kartal \& Günay, 1994., Zorba et al., 1995). We can say that these factors, which are important in sprint performance, are also important in acceleration performance, but muscular strength and muscular endurance affect performance much more effectively in sprint performance.

When we look at the studies in the literature, there are many studies on acceleration and speed. However, there are not many studies between foot sole and metatarsus measurements, acceleration and speed. In an another study, it is point out that there is no significant relationship between the balance scores of gymnasts who require a high level of balance performance and their speed, speed and agility performances (Sekulic et al., 2013). In a study on active football players, statistically positive correlations were found between balance values and acceleration (Y1lmaz et al., 2005). As a result, it was observed that there were differences between the groups in terms of acceleration performance, but there was no significant difference in terms of speed performance.

\section{References}

Andrzejewska, J., Burdukiewicz, A., Chromik, K., Pietraszewska, J., \& Stachoń, A. (2010). Morphological structure and characteristics of judo contestants' feet. Acta Bio-Opt Inf Med, 1, 21-24.

Bangsbo, J., Nørregaard, L., \& Thorsoe, F. (1991). Activity profile of competition soccer. Canadian Journal of Sport Sciences, 16(2), 110-116.

Erdoğan, C., Er, F., İpekoğlu, G., Çolakoğlu, T., Zorba, E., \& Çolakoğlu, F. (2017). Farklı denge egzersizlerinin voleybolcularda statik ve dinamik denge performansı üzerine etkileri. Spor ve Performans Araştırmaları Dergisi, 8(1), 11-18.

Facciono, A. (1993). Resisted and assisted methods for speed development. Strength Cond Coach, 1, 10-11.

Gambetta, V. (1996). In a blur: How to develop sport-specific speed. Sports Coach, 19, 22-24.

Kartal, R., \& Günay, M. (1994). Sezon öncesi yapılan hazırlık antrenmanlarının futbolcuların bazı fizyolojik parametrelerine etkisi. Spor Bilimleri Dergisi, 5(3), 24-31.

Koyuncu, G. (2013). 65 yaş üstü bireylerde denge durumunun değerlendirilmesi (Master's thesis, Trakya Üniversitesi, Turkey).

M.E.B. Megep. (2013). Ayakkabı ve Saraciye Teknolojisi. Ayakkabıda Ölçü Alma Modülü. Ankara, Turkey.

Murphy, A. J., Lockie, R. G., \& Coutts, A. J. (2003). Kinematic determinants of early acceleration in field sport athletes. Journal of Sports Science \& Medicine, 2(4), 144-150.

Sekulic, D., Spasic, M., Mirkov, D., Cavar, M., \& Sattler, T. (2013). Gender-specific influences of balance, speed, and power on agility performance. J Strength Cond Res, 27(3), 802-811. https://doi.org/10.1519/JSC.0b013e31825c2cb0 


\section{Macrothink}

Taşkın, C., \& Biçer, Y. (2015). The effect of an eight-week proprioception training program on agility, quickness and acceleration. Turkish Journal of Sport and Exercise, 17(2), 26-30. https://doi.org/10.15314/tjse.81867

Taşkın, C., Taşkın, A. K., Görgülü, T., \& Günay, M. (2020). Comparison of different foot base sizes with y balance test performance in sedentary women. European Journal of Physical Education and Sport Science, 6(8), 11-21.

Taşkın, C., Taşkın, A. K., Görgülü, T., \& Günay, M. (2020). Research of the effects of foot sizes on quickness and agility performance in sedentary wosmen. European Journal of Physical Education and Sport Science, 6(9), 31-40.

Taşkıran, Y. (2007). Antrenman Bilgisi (pp. 44-45-163). İstanbul: Akademi Basın ve Yayincilik.

Y1lmaz, A., Can, Y., \& Süer, C. (2005). The different balance parameters evaluation of the active soccer players. Sağllk Bilimleri Dergisi, 14(1), 36-42.

Zorba, E., Ziyagil, M. A., Çolak, H., Kalkavan, A., Kolukısa, Ş., Torun, K., \& Özdağ, S. (1995). 12-15 yaş grubu futbolcuların antropometrik ve fiziksel uygunluk değerlerinin sedanter grupla karşıllaştırılması. Futbol Bilim ve Teknoloji Dergisi, 3(1), 17-22.

\section{Copyright Disclaimer}

Copyright for this article is retained by the author(s), with first publication rights granted to the journal.

This is an open-access article distributed under the terms and conditions of the Creative Commons Attribution license (http://creativecommons.org/licenses/by/3.0/). 